\title{
Selectivity of Saflufenacil for Sweet Sorghum and Potential USE OF NA-BENTAZON AS A SAFENER ${ }^{1}$
}

\author{
Seletividade de Saflufenacil para Sorgo Sacarino e Potencial de Uso do Na-Bentazon como \\ Safener
}

CORREIA, N.M. ${ }^{2}$, and GOMES, L.J.P. ${ }^{3}$

\begin{abstract}
The objective of this study was to assess the selectivity herbicide saflufenacil for two sweet sorghum hybrids, when sprayed in preemergence and postemergence, besides the use of Na-bentazon as a 'safener' for saflufenacil. Three experiments were conducted, in pots, maintained in an ambient condition (second and third experiments) and in a greenhouse (first experiment). In each experiment a completely randomized distribution was used, with four replicates. In the first ( 2 x 6 factorial) two hybrids of sweet sorghum (CVSW 80007 and CVSW 80147) and six dosages $\left(0 ; 35 ; 52.5 ; 70 ; 87.5\right.$ and $\left.105 \mathrm{~g} \mathrm{ha}^{-1}\right)$ of saflufenacil were studied, applied in preemergence of the plants. In the second $(2 \times 5$ factorial) the same hybrids of sweet sorghum sprayed in postemergence with saflufenacil $\left(0 ; 35 ; 52.5 ; 70\right.$ and $\left.87.5 \mathrm{~g} \mathrm{~h}^{-1}\right)$ were assessed. In the third ( $4 \times 5$ factorial) the association of Na-bentazon $(0 ; 240 ; 480$ and $\left.720 \mathrm{~g} \mathrm{ha}^{-1}\right)$ to saflufenacil $\left(0.35 ; 52.5 ; 70\right.$ and $\left.87.5 \mathrm{~g} \mathrm{ha}^{-1}\right)$ was studied, when sprayed in postemergence on the sweet sorghum plants (CVSW 80007). Hybrid CVSW 80147 was more tolerant to saflufenacil than hybrid CVSW 800007, in preemergence or postemergence applications. The variables that best assessed the sensibility of the sweet sorghum to saflufenacil were number of emerged plants, for preemergence applications, and dry matter of stem for postemergence. Na-bentazon showed promise for use as 'safener' in postemergence applications of saflufenacil in sweet sorghum for dosages up to $70 \mathrm{~g} \mathrm{ha}^{-1}$.
\end{abstract}

Keywords: antidote, Basagran $600^{\circledR}$, phytotoxicity, Heat ${ }^{\circledR}$, Sorghum bicolor.

RESUMO - Objetivou-se estudar a seletividade do herbicida saflufenacil para dois híbridos de sorgo sacarino, quando pulverizado em pré e pós-emergência, além do uso de Na-bentazon como safener para saflufenacil. Três experimentos foram desenvolvidos, em vasos, mantidos em condição ambiente (segundo e terceiro experimento) e no interior de casa de vegetação (primeiro experimento). Em cada experimento, o delineamento experimental foi o inteiramente casualizado com quatro repetições. No primeiro (fatorial $2 \times 6$ ), foram avaliados dois híbridos de sorgo sacarino (CVSW $80007 e$ CVSW 80147) e seis dosagens (0; 35; 52,5; 70; 87,5; e $\left.105 \mathrm{~g} \mathrm{ha}{ }^{-1}\right)$ de saflufenacil, aplicado em préemergência das plantas. No segundo (fatorial $2 \times 5$ ), foram estudados os mesmos híbridos de sorgo sacarino pulverizados em pós-emergência com saflufenacil (0; 35; 52,5; 70; e 87,5 $\mathrm{g} \mathrm{ha}^{-1}$ ). No terceiro (fatorial $4 \times 5$ ), foi avaliada a associação do Na-bentazon (0, 240, 480 e $720 \mathrm{~g} \mathrm{ha}^{-1}$ ) ao saflufenacil (0; 35; 52,5; 70; e 87,5 $\mathrm{g} \mathrm{ha}^{-1}$ ), quando pulverizados em pós-emergência das plantas de sorgo sacarino (CVSW 80007). O híbrido CVSW 80147 foi mais tolerante ao saflufenacil do que o CVSW 80007, em aplicações em pré ou pós-emergência. As variáveis que melhor avaliaram a sensibilidade do sorgo sacarino ao saflufenacil foram número de plantas emergidas, para aplicações em pré-emergência, e matéria seca do caule, para pós-emergência. O Na-bentazon mostrou-se promissor para uso como safener nas aplicações em pós-emergência de saflufenacil em sorgo sacarino para dosagens de até $70 \mathrm{~g} \mathrm{ha}^{-1}$.

Palavras-chave: antídoto, Basagran $600^{\circledR}$, fitotoxicidade, Heat ${ }^{\circledR}$, Sorghum bicolor.

Recebido para publicação em 27.2.2015 e aprovado em 4.3.2015.

Embrapa, Brasília-DF, Brasil, <nubia.correia@embrapa.br>. ${ }^{3}$ UNESP, campus de Jaboticabal-SP, Brasil. 


\section{INTRODUCTION}

Herbicide saflufenacil is from the pyrimidinedione chemical group, inhibits protoporphyrinozen IX oxidase (PPO) enzyme, is rapidly absorbed by the roots and leaves of the plants and is translocated mainly by the xylem, with mobility limited by the phloem (Grossmann et al., 2011). In Brazil, this herbicide was recorded for applications in pre-sowing soybean, maize and wheat; in direct spray or as a defoliant in cotton crop desiccation (potatoes, beans), etc. (Agrofit, 2014). In the US, saflufenacil was also recorded for sorghum grain, in applications in presowing or post-sowing, in preemergence of the plants (Sharpen, 2014).

Among the types of sorghum (Sorghum bicolor), there is sweet sorghum, which can be used to produce ethanol from sugars directly fermentable in the culm. Research has already indicated the viability of sweet sorghum use in sugarcane harvests in Brazil, allowing the anticipation and the expansion of the crushing period by the companies plants (Teixeira et al., 1997). On the other hand, there are some doubts about the sweet sorghum yield system that need to be clarified, including the chemical control of weeds. One of the main barriers to the use of herbicides in this crop is the shortage of registered products, being only atrazine and 2.4-D (Rodrigues \& Almeida, 2011). This fact awakens the need for studies on herbicide selectivity for this crop and, through them, to stimulate the agrochemical companies for registration with the competent bodies.

Selectivity is the characteristic of the herbicides that enables its application to control weeds without damaging the crops. In general, selectivity is the result of differences in the response of a given plant species to a certain herbicide (Alterman \& Jones, 2003). However, selectivity depends on a number of other interrelated factors and can not be attributed solely to the herbicide, but to the applied dosage and the development stage of the plants. Soil, climate and the use of adjuvants can also change the degree of selectivity. Also in some cases selectivity varies as a function of the genetic material used (cultivars, hybrids, clones, etc.) (Alterman \& Jones, 2003).

Chemicals, called antidotes, safeners or protectors, may also be used in order to provide selectivity to certain herbicides, aiming increase the tolerance of cultivated species without affecting the sensitivity of weeds (Alterman \& Jones, 2003). In this regard, some herbicides are used as safeners of other herbicides, providing reduction of injuries to crops and increasing the application time (Moran et al., 2011). As examples, there are benoxacor for metolachlor in maize (Foy \& Witt, 1991; Viger et al., 1991), cyprosulfamide for isoxaflutole in maize (Nelson \& Penner, 2006), Na-bentazon for saflufenacil in maize (Moran et al., 2011) and tritosulfuron in wheat (Weinberg et al., 2007).

The protective effect of Na-bentazon was attributed to reduced absorption and translocation of the herbicide by plants (Weinberg et al., 2007; Moran et al., 2011). Interference in the foliar uptake was attributed to antagonism of ATPase by bentazon (Couderchet \& Retzlaff, 1991). However, other bentazon formulations, such as H-bentazon and $\mathrm{NH}_{3}$-bentazon, did not cause the same protective effect (Wanamarta et al., 1989; Weinberg et al., 2007).

This study was conducted with the hypothesis that the saflufenacil herbicide is selective for sweet sorghum, since sprayed in preemergence, in smaller doses, or in postemergence, when a safener is added (Na-bentazon). The objective was to study the selectivity of saflufenacil herbicide for sweet sorghum hybrids, when sprayed in preemergence and postemergence, besides the use of Na-bentazon as a safener for saflufenacil.

\section{MATERIALS AND METHODS}

Three experiments were carried out in the period from $01 / 09$ to $05 / 24 / 2013$, at Departamento de Fitossanidade at UNESP, Jaboticabal campus, SP.

In each experiment, the experimental design was completely randomized with four replications. In the first ( $2 \times 6$ factorial), two 
hybrids of sorghum were studied (CVSW 80007 and CVSW 80147) and six doses $(0 ; 35 ; 52.5$; 70; 87.5; and $105 \mathrm{~g} \mathrm{ha}^{-1}$ ) of saflufenacil were applied in preemergence of the plants. In the second ( $2 \times 5$ factorial), the same hybrids of sweet sorghum sprayed in postemergence with saflufenacil were assessed $(0 ; 35 ; 52.5 ; 70$; and $\left.87.5 \mathrm{~g} \mathrm{ha}^{-1}\right)$. In the third ( $4 \times 5$ factorial), the combination of Na-bentazon $(0,240,480$ and $\left.720 \mathrm{~g} \mathrm{ha}^{-1}\right)$ to saflufenacil $(0,35,52.5,70$, and $87.5 \mathrm{~g} \mathrm{~h}^{-1}$ ) was studied when sprayed in postemergence of the sweet sorghum plants (CVSW 80007).

Each experimental unit consisted of a plastic pot with a capacity of eight liters of soil. The pots were kept at ambient condition (second and third experiments) and inside a greenhouse (first experiment). As substrates, sand and organic compound were used to mix the soil at a ratio of $3: 1: 1$, respectively. The substrate presented pH 5.7; organic matter of $33 \mathrm{~g} \mathrm{dm}^{-3}$; $\mathrm{P}$ of $38 \mathrm{mg} \mathrm{dm}^{-3}$; and $\mathrm{K}, \mathrm{Ca}, \mathrm{MG}$ and CTC of 4.2, 37, 22 and $89 \mathrm{mmol}_{\mathrm{c}} \mathrm{dm}^{-3}$, respectively, having been classified as clayey, with 404, 441 and $155 \mathrm{~g} \mathrm{~kg}^{-1}$ of sand, silt and clay, respectively.

Ten sweet sorghum seeds were homogeneously distributed in the pot and incorporated up to $2 \mathrm{~cm}$ deep in the soil surface. Subsequently, in the postemergence experiments (second and third) thinning was done, remaining four plants per pot.

The products were applied in preemergence (soon after sowing) or in postemergence, with plants in stage V5. A backpack sprayer was used, at a constant pressure (maintained by compressed $\mathrm{CO}_{2}$ ) of $2.0 \mathrm{kgf} \mathrm{cm}^{-2}$, equipped with a bar with two flat fan nozzles TT 11002 , spaced $0.5 \mathrm{~m}$, with liquid consumption equivalent to $200 \mathrm{~L} \mathrm{ha}^{-1}$. Weather conditions at the time of application, besides date and time, are shown in Table 1.

In postemergence applications the non-ionic adjuvant (p.c. Dash ${ }^{\circledR}$ ) was added at $0.5 \% \mathrm{v} / \mathrm{v}$ to the saflufenacil spray (p.c. Heat ${ }^{\circledR}$ ), associated or not to Na-bentazon (p.c. Basagran $600^{\circledR}$ ).

At 42 days after application (DAA) in the first and second experiments, and at 49 DAA in the third, plant height, stem diameter and the dry matter of the stem, leaves and panicle (only in the third) were determined. In the first experiment, at 42 DAA the number of plants per pot was also assessed.

The data were submitted to the F test of analysis of variance. The effects of sorghum hybrids and dosing of saflufenacil (first and second experiments) or their interaction, when significant, were compared by Tukey test at $5 \%$ probability or by polynomial fit of the data. The effects of doses of saflufenacil and bentazon (third experiment) or the interaction thereof, when significant, were compared by polynomial fit of the data.

\section{RESULTS AND DISCUSSION}

In experiment 1 , in which the application of saflufenacil was studied in preemergence of the sweet sorghum plants, the hybrids of sorghum differed in number of plants, stem diameter, and dry matter of leaves (Table 2). The plants of hybrid CVSW 80147 had larger diameter stem and dry matter of the leaves than plants of hybrid CVSW 80007. However, these results were not dependent on the dosage of saflufenacil. It is then natural differences between the genetic materials studied.

There was a significant effect of the saflufenacil dosages and of the hybrid versus

Table 1 - Number of seeds or plants per pot, number of leaves per plant, number of seeds per pot, besides the date, time and weather condition at the time of the application of the products in the three experiments

\begin{tabular}{|l|c|c|c|c|c|c|c|c|c|}
\hline \multirow{2}{*}{ Experiment } & $\begin{array}{c}\text { Number of } \\
\text { seeds or plants } \\
\text { per pot }\end{array}$ & $\begin{array}{c}\text { Number of } \\
\text { leaves per } \\
\text { plant }\end{array}$ & Date & Time & \multicolumn{2}{|c|}{ Temperature $\left({ }^{\circ} \mathrm{C}\right)$} & \multirow{2}{*}{$\begin{array}{c}\text { Relative } \\
\text { humidity }(\%)\end{array}$} & \multirow{2}{*}{$\begin{array}{c}\text { Wind speed } \\
\left(\mathrm{km} \mathrm{h}^{-1}\right)\end{array}$} & \multirow{2}{*}{$\begin{array}{c}\text { Cloudiness } \\
(\%)\end{array}$} \\
\hline First & 5 & - & $2 / 8 / 2013$ & $9: 00-9: 55$ & $26.8-26.2$ & $23.8-24.2$ & $68-72$ & $0.0-0.7$ & $90-95$ \\
\hline Second & 4 & 5 & $2 / 8 / 2013$ & $9: 55-10: 40$ & $26.2-25.4$ & $24.2-24.7$ & $72-85$ & $0.7-0.0$ & $95-100$ \\
\hline Third & 4 & 5 & $4 / 6 / 2013$ & $8: 45-10: 00$ & $25.7-30.4$ & $24.3-28.6$ & $85-73$ & $0.0-0.0$ & $100-95$ \\
\hline
\end{tabular}


Table 2 - Results of the F test of the analysis of variance for number of plants per pot, plant height, stem diameter, dry matter of stem and leaves of sweet sorghum at 42 days after application (DAA) in preemergence of saflufenacil

\begin{tabular}{|c|c|c|c|c|c|}
\hline \multirow{2}{*}{ Sources of variation } & \multirow{2}{*}{$\begin{array}{l}\text { Number of } \\
\text { plants }\end{array}$} & \multirow{2}{*}{$\begin{array}{l}\text { Height of the } \\
\text { plant }\end{array}$} & \multirow{2}{*}{ Stem diameter } & \multicolumn{2}{|c|}{ Dry matter } \\
\hline & & & & Stem & Leaves \\
\hline Hybrid & $19.74 * *$ & 3.99 & $4.37 *$ & 0.04 & $5.14^{*}$ \\
\hline Saflufenacil & $5.26 * *$ & 2.60 & 0.98 & 1.44 & 1.04 \\
\hline Hybrid versus saflufenacil & $1.93 *$ & 0.82 & 1.12 & 1.11 & 0.63 \\
\hline CV $(\%)$ & 19.79 & 17.53 & 11.78 & 30.51 & 24.15 \\
\hline Hybrids & (uni.per pot) & $(\mathrm{cm})$ & $(\mathrm{mm})$ & \multicolumn{2}{|c|}{ (g per plant) } \\
\hline CVSW 80007 & $3.58 \mathrm{~b}^{\mathrm{1} /}$ & $52.24 \mathrm{a}$ & $9.05 \mathrm{~b}$ & $2.22 \mathrm{a}$ & $2.98 \mathrm{~b}$ \\
\hline CVSW 80147 & $4.62 \mathrm{a}$ & $47.22 \mathrm{a}$ & $9.72 \mathrm{a}$ & $2.18 \mathrm{a}$ & $3.49 \mathrm{a}$ \\
\hline DMS & 0.48 & 5.10 & 0.65 & 0.39 & 0.45 \\
\hline
\end{tabular}

**, * Significant at 1 and 5\% probability, respectively, by the $\mathrm{F}$ test of analysis of variance. ${ }^{1 /}$ Means followed by the same letter in the column do not differ significantly among themselves by the Tukey test at $5 \%$ probability.

saflufenacil interaction only for number of plants. Therefore, the greatest damage caused by the herbicide to the sweet sorghum was in the emergence of plants, since the surviving plants were not growth inhibited by the herbicide. In another study, higher doses of saflufenacil, sprayed in preemergence, reduced the population of plants, in some cases below acceptable levels, with a loss in grain yield with dosage over $40 \mathrm{~g} \mathrm{ha}^{-1}$ (Keeling et al., 2013).

Hybrid CVSW 80147 was not affected by doses of saflufenacil, unlike CVSW 80007, whose emergence decreased linearly with increasing dosage, with mortality of $52 \%$ of the plants with the dosage of $105 \mathrm{~g} \mathrm{ha}^{-1}$ of saflufenacil (Figure 1). The difference in sensitivity of sorghum hybrids to saflufenacil was also reported by Keeling et al. (2013), in which hybrid Pioneer 85G01 was more sensitive than Dekalb 44-20. Miller et al. (2012) have reported that soybean cultivar OAC Hanover was more sensitive to saflufenacil compared to the other 11 cultivars tested. These studies reinforce that the selectivity of herbicides for crops is also the result of the tested genetic material.

In preemergence, selectivity of saflufenacil for crops may be attributed to herbicide retention in the soil, which affects its availability in the soil solution and possible absorption by plants (Liebl et al., 2008). Thus, the texture and content of organic matter in the soil, besides rainfall or irrigation after application, directly interfere with the bioactivity of saflufenacil in the soil (Keeling et al., 2013). In the US, saflufenacil was recorded for sorghum grain at dosages up to $45 \mathrm{~g} \mathrm{ha}^{-1}$ for preemergence applications.

For other crops, saflufenacil at 50 and $70 \mathrm{~g} \mathrm{ha}^{-1}$, applied in preemergence, has caused no visible damage to potato plants or tubers decreased yield (Boydston et al., 2012). The same has occurred in maize plants at dosages up to $200 \mathrm{~g} \mathrm{ha}^{-1}$ for preemergence application. Maize has a natural tolerance to saflufenacil, due to its rapid metabolism for non-phytotoxic metabolites in shoot and root tissues, and less translocation from the site of absorption (roots) until the shoot tissues (Soltani et al., 2009).

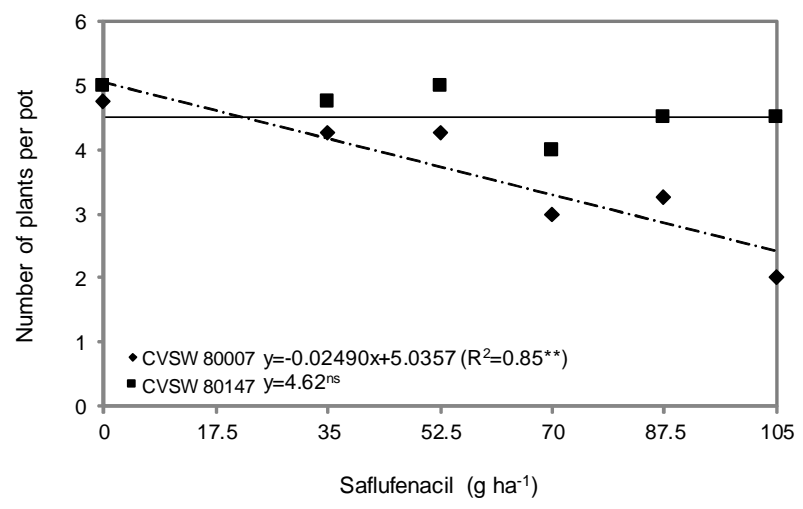

Figure 1 - Number of plants per pot of two hybrids of sweet sorghum at 42 days after application (DAA) in preemergence of different dosages of saflufenacil. 
In experiment 2, when saflufenacil was sprayed in postemergence of sweet sorghum plants, there were significant effects of sorghum hybrids in plant height, diameter and dry matter of the stem (Table 3 ). The saflufenacil dosages and the hybrid versus saflufenacil interaction have significantly influenced plant height, dry matter of stem and leaves.

Hybrid CVSW 80147 was more tolerant to saflufenacil than CVSW 80007, therefore, regardless of the dose sprayed, the plant height and dry matter of the stem and leaves were not inhibited by the herbicide (Figure 2). Nonetheless, for CVSW 80007, growth and mass accumulation by plants decreased linearly with increasing herbicide dosage. For each $10 \mathrm{~g}$ of saflufenacil there was a decrease of $3.1 \mathrm{~cm}$ in the height of the plants and of $1.1 \mathrm{~g}$ and $0.4 \mathrm{~g}$, respectively, in the dry matter of stem and leaves.

The application of saflufenacil did not affect the stem diameter of the plants. On the other hand, hybrid CVSW 80147 showed greater stem diameter than CVSW 80007, regardless of the sprayed herbicide dosage. These results relate to the natural differences between the genotypes studied.

Soltani et al. (2009) have found that maize had an acceptable tolerance to saflufenacil at dosages of $100 \mathrm{~g} \mathrm{ha}^{-1}$ when sprayed in postemergence. However, when added as an adjuvant to the spray liquid, the herbicide has caused severe injuries to the maize plants with reflection on grain yield (Soltani et al., 2009). In this study, to all herbicide sprays (experiments 2 and 3 ) was added a non-ionic adjuvant at $0.5 \% \mathrm{v} / \mathrm{v}$, as recommended by the manufacturer for use in postemergence. This may have contributed to an increased uptake of the herbicide by plants and thus greater phytotoxic effect, especially in hybrid CVSW 80007. Failure in adding an adjuvant to the sprays of saflufenacil may contribute to the selectivity of the herbicide for crops, but may reflect in an ineffective weed control.

In experiment 3 , in which the application of saflufenacil alone and mixed with bentazon was assessed, the single factors and the interaction of these were significant for all characteristics assessed, except for stem diameter, in which there was no significant interaction effect (Table 4). For this variable, the values increased linearly with increasing dosages of bentazon, yielding up to $11 \%$ increase (Figure 3), unlike saflufenacill, which gave rise to a linear reduction in diameter of the stem by increasing the dose, with $11 \%$ decrease at the highest dosage (87.5 $\mathrm{g} \mathrm{ha}^{-1}$ ).

When unfolding the saflufenacil versus bentazon interaction, there was an option for the analysis of bentazon dosages within each dosage of saflufenacil. Without the addition of saflufenacil to the sprays, increasing bentazon dosages (up to $720 \mathrm{~g} \mathrm{ha}^{-1}$ ) did not affect the height and dry matter of stem, leaves and

Table 3 - Results of the F test of the analysis of variance for plant height, stem diameter, dry matter of stem and leaves of sweet sorghum at 42 days after application (DAA) in postemergence of saflufenacil

\begin{tabular}{|c|c|c|c|c|}
\hline \multirow{2}{*}{ Sources of variation } & \multirow{2}{*}{ Height of the plant } & \multirow{2}{*}{ Stem diameter } & \multicolumn{2}{|c|}{ Dry matter } \\
\hline & & & Stem & Leaves \\
\hline Hybrid & $45.37 * *$ & $6.62 *$ & $13.09 * *$ & 0.73 \\
\hline Saflufenacil & $8.01 * *$ & 1.90 & $7.82 * *$ & $3.94 * *$ \\
\hline Hybrid versus saflufenacil & $3.84^{*}$ & 2.21 & $4.63 * *$ & $1.94^{*}$ \\
\hline $\mathrm{CV}(\%)$ & 15.56 & 7.57 & 23.35 & 18.33 \\
\hline Hybrids & $(\mathrm{cm})$ & $(\mathrm{mm})$ & \multicolumn{2}{|c|}{ (g per plant) } \\
\hline CVSW 80007 & $49.20 \mathrm{a}^{\frac{1}{}}$ & $15.21 \mathrm{~b}$ & $10.74 \mathrm{a}$ & 8.93 a \\
\hline CVSW 80147 & $35.21 \mathrm{~b}$ & $16.18 \mathrm{a}$ & $8.02 \mathrm{~b}$ & $9.39 \mathrm{a}$ \\
\hline DMS & 4.24 & 0.77 & 1.54 & 1.08 \\
\hline
\end{tabular}

**, * Significant at 1 and $5 \%$ probability, respectively, by the $\mathrm{F}$ test of analysis of variance. ${ }^{1 /}$ Means followed by the same letter in the column do not differ significantly among themselves by the Tukey test at $5 \%$ probability. 


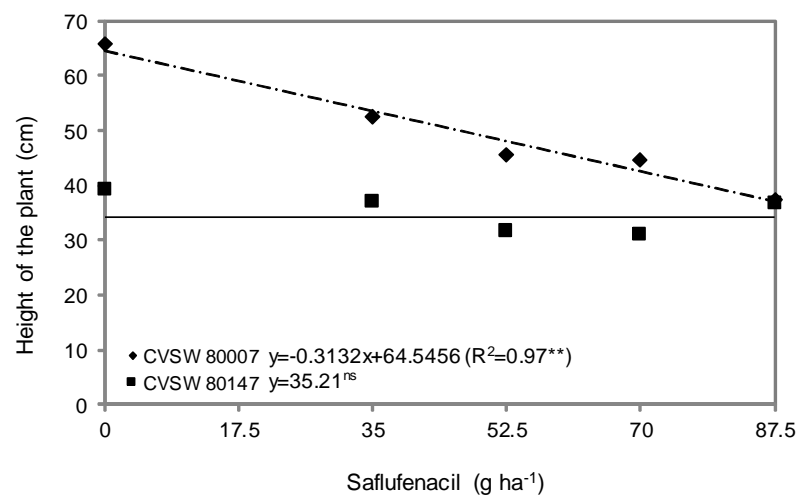

panicles of sorghum plants (Figure 4). In turn, the association of bentazon to the dosages of $35,52.5$ and $70 \mathrm{~g} \mathrm{ha}^{-1}$ of saflufenacil contributes to the protection of plants from the negative effect of the herbicide, because, due to to increase of the dosage of bentazon, the plant height and the dry matter of stem, leaves and panicles increased. The same was observed for height and dry matter of the panicle with the application of $87.5 \mathrm{~g} \mathrm{ha}^{-1}$. However, for dry matter of stem and leaves, in
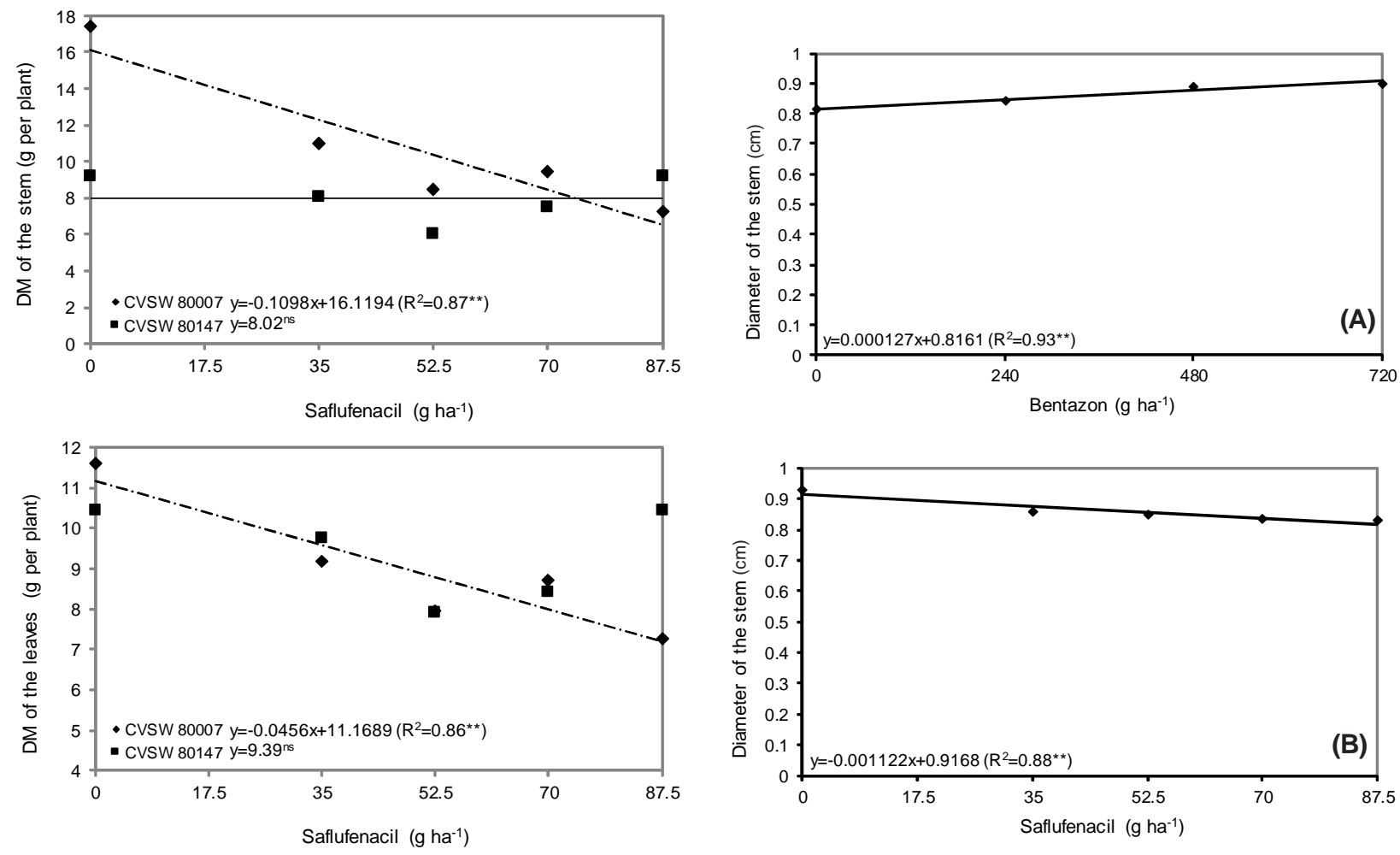

Figure 2 - Plant height and dry matter of stem and leaves of two hybrids of sweet sorghum at 42 days after application (DAA) in postemergence of different dosages of saflufenacil.

Figure 3 - Stem diameter of the plants of sweet sorghum at 49 days after application (DAA) in postemergence of herbicides bentazon (A) and saflufenacil (B).

Table 4 - Results of the F test of the analysis of variance for plant height, stem diameter, dry matter of the stem, leaves, panicle and total (stem + leaves + panicle) of sweet sorghum at 49 days after application (DAA) in postemergence of saflufenacil and bentazon

\begin{tabular}{|c|c|c|c|c|c|}
\hline \multirow{2}{*}{ Sources of variation } & \multirow{2}{*}{ Height of the plant } & \multirow{2}{*}{ Stem diameter } & \multicolumn{3}{|c|}{ Dry matter } \\
\hline & & & Stem & Leaves & Panicle \\
\hline Bentazon & $13.91^{* *}$ & $10.76^{* *}$ & $16.86^{* *}$ & $20.15^{* *}$ & $21.40^{* *}$ \\
\hline Saflufenacil & $9.49 * *$ & $8.38^{* *}$ & $35.35^{* *}$ & $40.34^{* *}$ & $21.47^{* *}$ \\
\hline Bentazon versus saflufenacil & $1.67 * *$ & 1.45 & $3.20 * *$ & $4.05^{* *}$ & $2.43^{* *}$ \\
\hline $\mathrm{CV}(\%)$ & 8.90 & 6.46 & 16.51 & 9.62 & 16.11 \\
\hline
\end{tabular}

**, * Significant at 1 and 5\% probability, respectively, by the $\mathrm{F}$ test of analysis of variance. 

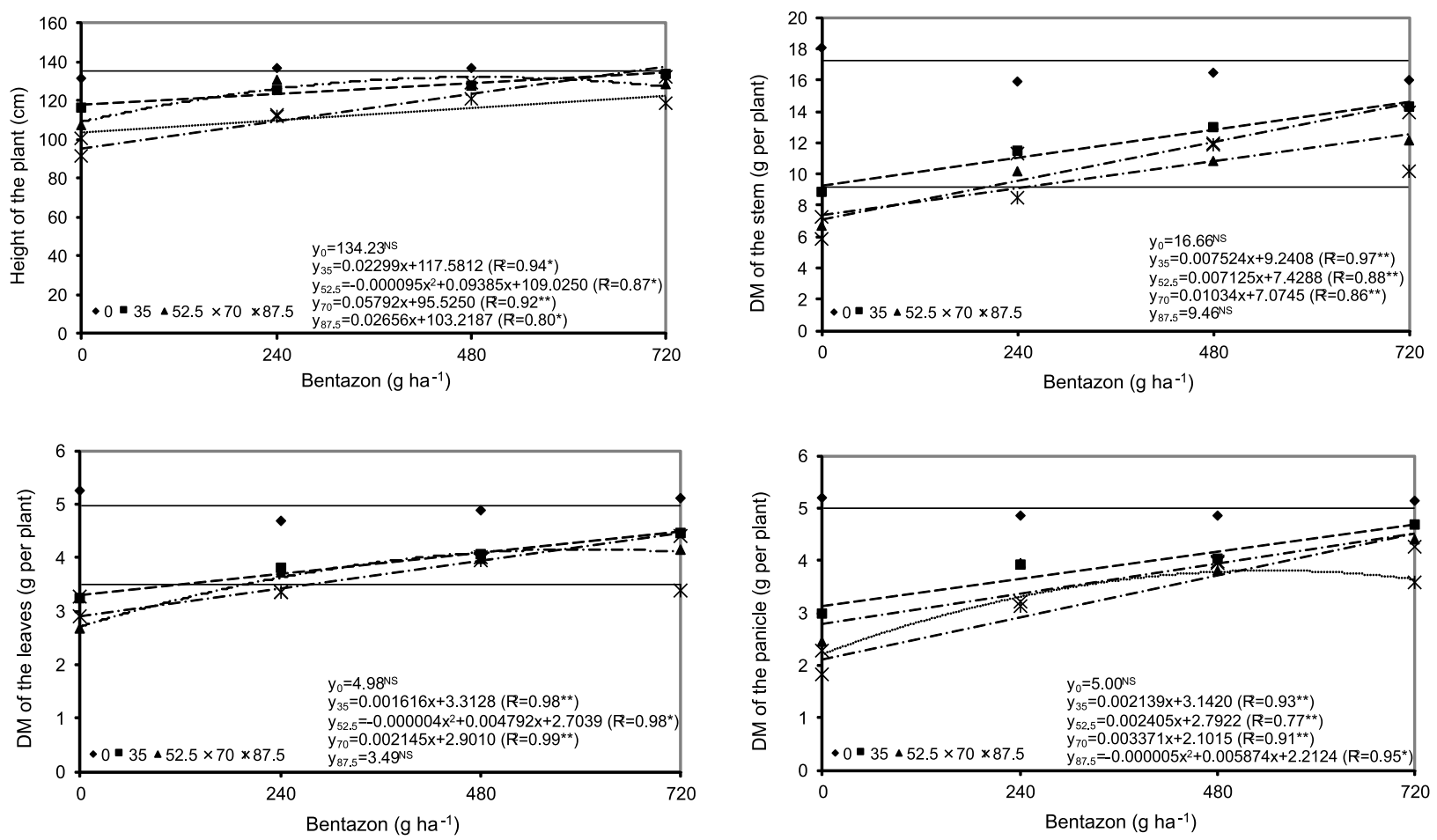

Figure 4 - Height and dry matter of the stem, leaves and panicles of sweet sorghum plants at 49 days after application (DAA) in postemergence of saflufenacil $\left(0,35,52.5,70\right.$, and $\left.87.5 \mathrm{~g} \mathrm{ha}^{-1}\right)$ associated with bentazon $\left(0,240,480\right.$ and $\left.720 \mathrm{~g}^{-1}\right)$ - unfolding of the interaction.

the highest dosage of saflufenacil there was no significant difference between the dosages of bentazon with the application of $87.5 \mathrm{~g} \mathrm{ha}^{-1}$. As the yield of ethanol by sweet sorghum is performed directly from fermentable sugars in the culm, the stem dry matter has great importance in defining the sensitivity levels of the plants to certain herbicides.

In another study, saflufenacil (25 and $50 \mathrm{~g} \mathrm{ha}^{-1}$ ), applied in postemergence, has reduced by 33 and 34\% the dry matter of wheat plants; however, with the addition of bentazon (560 $\mathrm{g} \mathrm{ha}^{-1}$ ) to the sprays this negative effect was not observed (Frihauf et al., 2010). Moran et al. (2011) have reported that the combination of Na-bentazon to saflufenacil has reduced noticeable injuries and increased the height, dry matter of plants and the yield of maize, compared to the isolated application of saflufenacil.

There are two main mechanisms by which the antidotes reduce the damage caused by herbicides on crops, both related to the increase in metabolism and detoxification of herbicides (Alterman \& Jones, 2003). The first corresponds to an increase in glutathione levels and/or activity of GSH-S-transferase enzyme. The second is related to the increase in the activity or the amount of cytochrome P450 mono-oxygenase. These enzymes can reduce the activity of the herbicides by means of oxidation reactions, which often precede reactions of conjugation with glucose in the presence of glucosyltransferases enzymes (Alterman \& Jones, 2003).

The results have indicated that hybrid CVSW 80147 was more tolerant to herbicide saflufenacil than CVSW 80007 in preemergence or postemergence applications. The variables that best assessed the sensitivity of sweet sorghum to saflufenacil were the number of emerged plants, for preemergence applications, and dry matter of the stem, in postemergence. Na-bentazon has shown promise for use as a safener for applications in postemergence of saflufenacil on sweet sorghum (hybrid CVSW 80007) for dosages up to $70 \mathrm{~g} \mathrm{ha}^{-1}$. 


\section{LITERATURE CITED}

AGROFIT. Sistema de agrotóxicos fitossanitários. Disponível em: <http://extranet.agricultura.gov.br/ agrofit_cons/principal_agrofit_cons $>$. Acesso em: 22 set. 2014.

ALTERMAN, M. K.; JONES, A. P. Herbicidas: fundamentos fisiológicos y bioquímicos del modo de acción. Santiago do Chile: Universidad Católica de Chile, 2003. 333 p.

BOYDSTON, R. A.; FELIX, J.; AL-KHATIB, K. Preemergence herbicides for potential use in potato production. Weed Technol., v. 26, n. 4, p. 731-739, 2012.

COUDERCHET, M.; RETZLAFF, G. The role of the plasma membrane ATPase in bentazone-sethoxydim antagonism. Pest. Sci., v. 32, n. 3, p. 295-306, 1991.

FOY, C. L.; WITT, H. L. Effects of safener CGA-154281 on metolachlor/atrazine injury to corn (Zea mays).

Weed Technol., v. 5, n. 2, p. 325-330, 1991.

FRIHAUF, J. C.; STAHLMAN, P. W.; GEIER, P. W. Winter wheat and weed response to postemergence saflufenacil alone and in mixtures. Weed Technol., v. 24, n. 3, p. 262-268, 2010.

GROSSMANN, K. et al. Saflufenacil (Kixor ${ }^{\mathrm{TM}}$ ): Biokinetic Properties and Mechanism of Selectivity of a New Protoporphyrinogen IX Oxidase Inhibiting Herbicide. Weed Sci., v. 59, n. 3, p. 290-298, 2011.

KEELING, J. W. et al. Grain sorghum response to saflufenacil applied preemergence. Crop Protec., v. 46, n. 1, p. 1-6, 2013.

LIEBL, R. et al. BAS 800H: a new herbicide for preplant burndown and preemergence dicot weed control. In: WEED SCIENCE SOCIETYOFAMERICA CONFERENCE, 48., 2008, Lawrence. Abstract. . . Lawrence: Weed Science Society of America, 2008. p. 120.

MILLER, R. T. et al. Soybean (Glycine max) cultivar tolerance to saflufenacil. Can. J. Plant Sci., v. 92, n. 7, p. 1319-1328, 2012.
MORAN, M. et al. Sodium safens saflufenacil applied postemergence to corn (Zea mays). Weed Sci., v. 59, n. 1, p. 4-13, 2011.

NELSON, E. A.; PENNER, D. Reduction of isoxaflutole injury to corn (Zea mays) with herbicide safeners and water-repellent adjuvants. Weed Technol., v. 20, n. 4, p. 999-1003, 2006.

RODRIGUES, B. N.; ALMEIDA, F. S. Guia de herbicidas. 6.ed. Londrina: 2011.697 p.

SHARPEN. Sharpen powered by Kixor herbicide. Disponível em: <http://www.agproducts.basf.us/ products/research-library/kixor-sharpen-technicalinformation-bulletin.pdf>. Acesso em: 8 mar. 2014.

SOLTANI, N.; SHROPSHIRE, C.; SIKKEMA, P. H. Response of corn to preemergence and postemergence applications of saflufenacil. Weed Technol., v. 23, n. 3, p. 331-334, 2009.

SHROPSHIRE, C.; SIKKEMA, P. H. Response of corn to preemergence and postemergence applications of saflufenacil. Weed Technol., v. 23, n. 3, p. 331-334, 2009.

TEIXEIRA, C. G.; JARDINE, J. G; BEISMAN, D. A. Utilização do sorgo sacarino como matéria-prima complementar à cana-de-açúcar para obtenção de etanol em microdestilaria. Ci. Tecnol. Alimentos, v. 17, n. 3, p. 221-229, 1997.

VIGER, P. R.; EBERLEIN, C. V.; FUERST, E. P. Influence of available soil water content, temperature, and CGA154281 on metolachlor injury to corn. Weed Sci., v. 39, n. 2, p. 227-231, 1991.

WANAMARTA, G.; PENNER, D.; KELLS, J. J. The basis of bentazon antagonism on sethoxydim absorption and activity. Weed Sci., v. 37, n. 3, p. 400-404, 1989.

WEINBERG, T. et al. Basis for antagonism by sodium bentazon of tritosulfuron toxicity to white bean (Phaseolus vulgaris L.). J.Agric. Food Chemistry, v. 55, n. 6, p. 2268-2275, 2007. 